\title{
FAKTOR YANG MEMPENGARUHI POLA MAKAN DENGAN TIMBULNYA KARIES GIGI PADA ANAK USIA SEKOLAH DI SEKOLAH DASAR NEGERI 4 AMARANG KECAMATAN TANRALILI KABUPATEN MAROS
}

\author{
Andi Basari ${ }^{1}$, Sitti Nurbaya ${ }^{2}$, Yasir Haskas ${ }^{3}$ \\ ${ }^{1}$ STIKES Nani Hasanuddin Makassar \\ ${ }^{2}$ STIKES Nani Hasanuddin Makassar \\ ${ }^{3}$ STIKES Nani Hasanuddin Makassar \\ Alamat Korespondensi: (andisariii01@gmail.com/082290187706)

\begin{abstract}
ABSTRAK
Karies gigi adalah penyakit jaringan gigi yang di tandai dengan kerusakan jaringan, dimulai dari permukaan gigi (ceruk, fiusra, dan daerah interproksimal) meluas ke arah (Braurer). Makanan kariogenik adalah makanan yang dapat menyebabkan terjadinya karies gigi. Sifat makanan kariogenik adalah banyak mengandung karbohidrat, lengket dan mudah hancur di dalam mulut. Tujuan penelitian ini adalah untuk mengetahui pengaruh jenis makanan,frekuensi makanan,dan jumlah makanan. Penelitian ini merupakan penelitian cros sectional dengan rancangan penelitian Total sampling. Populasi dalam penelitian ini adalah kelas III, VI, V dan IV sebanyak 65 siswa dan didapatkan 65 responden yang sesuai dengan kriteria inklusi. Pengumpulan data dilakukan dengan menggunakan lembar kuesioner. Data yang terkumpul kemudian diolah dan dianalisis dengan menggunakan Microsoft exel dan program statistic (SPSS). Hasil penelitian ini menujukkan bahwa pengaruh jenis makanan 0,003 , variabel frekuensi makanan sebesar 0,431 ,dan variabel jumlah makanan sebesar 0,494.Kesimpulan penelitian ini adalah ada pengaruh jenis makanan dengan timbulnya karies gigi, tidak ada pengaruh frekuensi makanan dengan timbulnya karies gigi, dan tidak pengaruh jumlah makanan dengan timbulnya karies gigi pada anak usia sekolah di Sekolah Dasar Negri 4 Amarang Kecamatan Tanralili Kabupaten Maros.
\end{abstract}

Kata Kunci : Anak, Karies Gigi, Pola Makan

\section{PENDAHULUAN}

Prevalensi nasional masalah gigi dan mulut adalah 25,9 \%, sebanyak 14 provinsi yang mempunyai prevalensi masalah gigi dan mulut diatas angka nasional yaitu Riau, Jambi, Sumatera Selatan, Bangka Belitung, Yoyakarta, Jawa Timur, Kalimantan Barat, Kalimantan Tengah, Kalimantan Selatan, Kalimantan Timur, Sulawesi Utara, Sulawesi Tengah, Sulawesi Tenggara dan Maluku. Prevalensi nasional menyikat gigi setiap hari adalah 94,2 \% dan sebanyak 15 provinsi berada dibawah prevalensi nasional. Untuk perilaku benar dalam menyikat gigi ditemukan sebagian besar penduduk indonesia menyikat gigi pada saat mandi pagi maupun mandi sore $(76,6 \%)$. Menyikat gigi dengan benar adalah setelah makan pagi dan sebelum tidur malam, untuk indonesia ditemukan hanya $2,3 \%$. Prevalensi penyakit karies gigi di Indonesia cenderung meningkat. Sekitar $70 \%$ dari karies yang ditemukan merupakan karies awal. Sedangkan jangkauann pelayanan belum memadai sehubungan dengan keadaan geografis indonesia yang sangat bervariasi. Prevalensi karies gigi tinggi yaitu $97,5 \%$; pengalaman karies (DMF-T) mendekati 2,84 pada kelompok umur 12 tahun ( Hestiani dkk, 2016).

Karies gigi sejauh ini masih menjadi masalah kesehatan anak. Organisasi Kesehatan Dunia (WHO) tahun 2016 menyatakan angka kejadian karies pada anakmasih sebesar $60-90 \%$. Menurut hasil penelitian di negara - negara Eropa, Amerikadan Asia termasuk Indonesia, ternyata bahwa90 - 100\% anak di bawah 18 tahun terserang karies gigi.

Menurut Riskesdas 2017 di Indonesia terjadi peningkatan prevalensi terjadinyakaries aktif pada penduduk Indonesia dibandingkan tahun 2010 lalu, yaitu dari 43,4 \% (2007) menjadi 53,2 \% atau 93 juta jiwa.

Kadis Kesehatan Sulsel $\mathrm{Dr}$ Bachtiar Baso mengatakan untuk mengeliminasi prevalensi caries (gigi berlubang) yang masih 35 persen di Sulsel atau tertinggi ketiga nasional, pihaknya bekerja sama dengan Fakultas Kedokteran Gigi Unhas dan para pemangku kebijakan dalam mencapai target 2030 Indonesia bebas caries. 
Menurut penelitian yang dilakukan Prasetyo mengungkapkan bahwa tingkat pengetahuan merupakan faktor luar yang mempengaruhi kejadian karies gigi. Semakin baik tingkat pengetahuannya maka semakin kecil kemungkinan terjadinya karies gigi..

Pravalensi karies gigi yang terdapat di Sekolah Dasar Negri 4 Amarang Kecamatan Tanralili Kabupaten Maros dari Kelas 3 sampai dengan Kelas 6 sebanyak 65 siswa dan sebagian besar yang menderita karies gigi terdapat di kelas 3 di Sekolah Dasar Negeri 4 amarang menderita Karies Gigi.

Berdasarkan data di atas tersebut peneliti tertarik melakukan penelitian dengan judul Faktor Yang Mempengaruhi Pola Makan Dengan Timbulnya Karies Pada Anak Usia Sekolah Di Sekolah Dasar Negri 4 Amarang Kecamatan Tanralili Kabupaten Maros.

\section{BAHAN DAN METODE}

Lokasi, populasi, dan sampel

Penelitian ini dilaksanakan di Sekolah Dasar Negeri 4 Amarang Kecamatan Tanralili Kabupaten Maros pada tanggal 01 Desember 2018 sampai 31 Januari 2019. populasi penelitian adalah seluruh siswa yang duduk di kursi kelas 3 sampai dengan kelas 6 sebanyak 65 siswa di Sekolah Dasar Negri 4 Amarang Kecamatan Tanralili Kabupaten Maros. dimana terdapat 35 anak yang berjenis kelamin laki-laki dan 30 berjenis kelamin perempuan dengan sampel didapatkan 65 anak teknik total sampling. Sampel tersebut kemudian dipilah berdasarkan karakteristik dan kriteria sampel berdasarkan:

1. Kriteria Inklusi:
a. Anak usia sekolah kelas 3 sampai 6
b. Dapat membaca dan menulis
c. Bersedia untuk di teliti

2. Kriteria Eksklusi :
a. Bukan anak usia sekolah kelas 3 sampai 6
b. Tidak dapat membaca dan menulis
c. Tidak bersedia untuk di teliti.

\section{Pengumpulan data}

1. Data primer

Dalam penelitian ini,seluruh data
diambil secara langsung dari responden,yang meliputi data tentang faktor yang mempengaruhi pola makan ndengan timbulnya karies gigi pada anak usia sekolah di SD Negeri 4 Amarang, data diukur menggunakan kuesioner. Data jenis makan menggunakan alat ukur kuesioner dengan menggunakan skala guttman, frekuensi makanan menggunakan alatb ukur kuesioner dengan menggunakan skala liker, dan jumlah makanan menggunakan alat ukur kuesioner dengan menggunakan skala liker.

2. Data sekunder

Data yang di nperoleh dari Tata Usaha di SD Negeri 4 Amarang.

\section{Pengolahan Data}

1. Editing

Editing di lakukan untuk meneliti setiap daftar pertanyaan yang sudah di isi, meliputi kelengkapan pengisian, kesalahan pengisian dan konsistensi dari setiap jawaban.

2. Koding

Merupakan tahap selanjutnya yaitu dengan memberi kode pada jawaban responden.

3. Tabulasi Data

Setelah dilakukan editing dan koding dilanjutkan dengan pengolahan data kedalam suatu tabel menurut sifat sifat yang dimiliki sesuai dengan tujuan penelitian.

\section{Analisa data}

1. Analisa Univariat

Dilakukan untuk mendapatkan gambaran umum dengan cara mendiskripsikan tiap variabel yang digunakan dalam penelitian dengan melihat distribusi frekuensi, mean, median dan modus.

2. Analisa Bivariat

Dilakukan untuk melihat hubungan antara variabel bebas secara sendiri sendiri dengan variabel terikat dengan menggunakan uji statistik Chi-Square, SPSS 16,00

\section{HASIL PENELITIAN}

1. Analisis univariat

Tabel 1. Analisis Karakteristik Responden di SD Negri 4 Amarang Kecamtan Tanralili Kabupaten Maros Tahun 2018.

\begin{tabular}{|c|c|c|}
\hline Karakteristik & $\mathrm{n}$ & $\%$ \\
\hline $\begin{array}{c}\text { Umur } \\
8 \text { tahun }\end{array}$ & 8 & 12,3 \\
\hline 9 tahun & 8 & 12,3 \\
\hline 10 tahun & 14 & 21,5 \\
\hline 11 tahun & 20 & 30,8 \\
\hline 12 tahun & 15 & 23,1 \\
\hline $\begin{array}{c}\text { Jenis Kelamin } \\
\text { Laki-laki }\end{array}$ & 35 & 53,8 \\
\hline Perempuan & 30 & 46,2 \\
\hline $\begin{array}{c}\text { Kelas } \\
\text { Kelas III }\end{array}$ & 12 & 18,5 \\
\hline Kelas IV & 15 & 23,1 \\
\hline Kelas V & 18 & 27,7 \\
\hline Kelas VI & 20 & 30,8 \\
\hline
\end{tabular}


Berdasarkan tabel 1 menunjukka $\mathrm{n}$ bahwa umur responden terbanyak adalah 11 tahun sebanyak 20 responden $(30,8 \%)$, umur 12 tahun 15 responden $(23,1 \%)$, umur 10 tahun 14 responden $(21,5 \%)$ terendah umur 9 tahun 8 responden $(12,3 \%)$ dan umur 8 tahun 8 responden $(12,3 \%)$ berjenis kelamin laki-laki sebanyak 35 responden $(53,8 \%)$, kelas VI sebanyak 20 responden $(30,8 \%)$, Kelas $\vee$ Sebanyak 18 responden $(27,7 \%)$, kelas IV Sebanyak 15 responden $(23,1 \%)$ dan kelas III sebanyak 12 responden (18,5\%).

2. Analisis Bivariat

Tabel 2. Pengaruh Jenis Makanan dengan Timbulnya Karies Gigi di Sekolah Dasar Negeri 4 Amarang Kecamatan Tanralili Kabupaten Maros

\begin{tabular}{|c|c|c|c|c|c|c|}
\hline \multirow{2}{*}{$\begin{array}{c}\text { Jenis } \\
\text { Makanan }\end{array}$} & \multicolumn{4}{|c|}{$\begin{array}{c}\text { Karies Gigi } \\
\text { gaigi }\end{array}$} & $\begin{array}{c}\text { Tidak } \\
\text { karies gigi }\end{array}$ & \multicolumn{2}{c|}{ Totai } \\
\cline { 2 - 7 } & $\mathrm{n}$ & $\%$ & $\mathrm{n}$ & $\%$ & $\mathrm{n}$ & $\%$ \\
\hline Kariogenik & 34 & 52,3 & 2 & 3,1 & 36 & 55,4 \\
\hline $\begin{array}{c}\text { Tidak } \\
\text { kariogenik }\end{array}$ & 18 & 27,7 & 11 & 16,9 & 29 & 44,6 \\
\hline Total & 52 & 80 & 13 & 20 & 65 & 100 \\
\hline \multicolumn{7}{|c|}{0,003} \\
\hline
\end{tabular}

Berdasarkan hasil uji statistik dengan Chi-square diperoleh nilai $p=0,003$. Karena nilai $p<\alpha=0,05$, maka hipotesis nol ditolak dan hipotesis alternatif diterima. Interpretasi ada pengaruh jenis makanan dengan timbulnya karies gigi pada anak usia sekolah di Sekolah Dasar Negeri 4 Amarang.

Tabel 3. Pengaruh Frekuensi Makanan dengan Timbulnya Karies Gigi di Sekolah Dasar Negeri 4 Amarang Kecamatan Tanralili Kabupaten Maros

\begin{tabular}{|c|c|c|c|c|c|c|}
\hline \multirow{2}{*}{$\begin{array}{c}\text { Frekuensi } \\
\text { Makanan }\end{array}$} & \multicolumn{3}{|c|}{ Karies Gigi } & \multicolumn{2}{|c|}{} \\
\cline { 2 - 6 } & Karies gigi & $\begin{array}{c}\text { Tidak } \\
\text { karies gigi }\end{array}$ & \multicolumn{2}{c|}{ Totai } \\
\cline { 2 - 6 } & $\mathrm{n}$ & $\%$ & $\mathrm{n}$ & $\%$ & $\mathrm{n}$ & $\%$ \\
\hline $\begin{array}{c}\text { Sering } \\
\text { Tidak } \\
\text { sering }\end{array}$ & 16 & 24,6 & 3 & 4,6 & 19 & 29,2 \\
\hline Total & 56 & 55,4 & 10 & 15,4 & 46 & 70,8 \\
\hline \multicolumn{8}{|c|}{0,431} & 13 & 20 & 65 & 100 \\
\hline
\end{tabular}

Berdasarkan Hasil uji statistik dengan Chi-square diperoleh nilai $p=0,431$. Karena nilai $p>\alpha=0,05$, maka hipotesis nol diterima dan hipotesis alternatif ditolak. Interpretasi tidak ada pengaruh frekuensi makanan dengan timbulnya karies gigi pada anak usia sekolah di Sekolah Dasar Negeri 4 Amarang.
Tabel 4. Pengaruh Jumlah Makanan dengan Timbulnya Karies Gigi di Sekolah Dasar Negeri 4 Amarang Kecamatan Tanralili Kabupaten Maros

\begin{tabular}{|c|c|c|c|c|c|c|}
\hline \multirow{3}{*}{$\begin{array}{l}\text { Jumlah } \\
\text { Makanan }\end{array}$} & \multicolumn{4}{|c|}{ Karies Gigi } & \multirow{2}{*}{\multicolumn{2}{|c|}{ Totai }} \\
\hline & \multicolumn{2}{|c|}{ Karies gigi } & \multicolumn{2}{|c|}{$\begin{array}{c}\text { Tidak } \\
\text { karies gigi }\end{array}$} & & \\
\hline & $\mathrm{n}$ & $\%$ & $\mathrm{n}$ & $\%$ & $\mathrm{n}$ & $\%$ \\
\hline Banyak & 7 & 10,8 & 1 & 1,5 & 8 & 12,3 \\
\hline $\begin{array}{c}\text { Tidak } \\
\text { banyak }\end{array}$ & 45 & 69,2 & 12 & 18,5 & 57 & 87,7 \\
\hline Total & 52 & 80 & 13 & 20 & 65 & 100 \\
\hline \\
\hline
\end{tabular}

Berdasarkan hasil uji statistik dengan Chi-square diperoleh nilai $p=0,494$. Karena nilai $p>\alpha=0,05$, maka hipotesis nol diterima dan hipotesis alternatif ditolak. Interpretasi tidak ada pengaruh jumlah makanan dengan timbulnya karies gigi pada anak usia sekolah di Sekolah Dasar Negeri 4 Amarang.

\section{PEMBAHASAN}

1. Pengaruh jenis makanan dengan timbulnya karies gigi pada anak usia sekolah.

Berdasarkan penelitian yang telah dilakukan di Sekolah Dasar Negeri 4 Amarang Kecamatan Tanralili Kabupaten Maros didapatkan hasil uji statistik dengan Chi-square diperoleh nilai $p=0,003$. Karena nilai $p<\alpha=0,05$, maka hipotesis nol ditolak dan hipotesis alternatif diterima. Interpretasi ada pengaruh jenis makanan dengan timbulnya karies gigi pada anak usia sekolah di Sekolah Dasar Negeri 4 Amarang, karena responden jenis makananya kariogenik lebih cenderung mengalami karies gigi.

Jenis makanan yang sering dikomsumsi dapat mempengaruhi keparahan karies gigi. Salah satu makanan yang banyak mengandung gula atau sukrosa mempunyai kemampuan yang lebih efisien terhadap pertumbuhan mikroorganisme dan dimetabolisme dengan cepat dalam menghasilkan zat-zat asam. Makanan yang menempel pada permukaan gigi jika dibiarkan akan menghasilkan zat asam lebih banyak, sehingga mempertinggi resiko karies gigi (Kartikasari \& Nuryanto, 2014).

Hasil penelitian ini sejalan dengan penelitian yang telah dilakukan oleh Febrian, dkk., (2015), menunjukkan bahwa ada hubungan bermakna antara jenis jajanan kariogenik dengan kejadian karies rampan dengan $p$ value $=0,005$. Sukrosa merupakan gabungan dari dua macam gula yaitu glukosa dan fruktosa. Jenis makanan yang mengandumg sukrosa dianggap lebih 
berbahaya dari gula lainnya karena mampu memproduksi lebih banyak perekat glukan untuk membuat plak dalam mulut semakin tebal dan lengket.

Menurut asumsi peneliti, terdapat pengaruh antara jenis makanan dengan timbulnya karies gigi pada anak usia sekolah, karena responden jenis makananya kariogenik lebih cenderung mengalami karies gigi. Jadi, dapat disimpulkan bahwa siswa yang mengkonsumsi jenis makanan kariogenik lebih berisiko tinggi terjadinya karies gigi. Jenis makanan kariogenik yang dikonsumsi siswa dapat mempengaruhi timbulnya karies gigi pada siswa karena makanan tersebut lebih mudah melengket di mulut yang dapat mikroorganisme berkembang di mulut sehingga apabila tidak ada kebiasaan menggosok gigi yang baik dapat berdampak terjadinya karies gigi pada siswa.

2. Pengaruh frekuensi makanan dengan timbulnya karies gigi pada anak usia sekolah.

Berdasarkan penelitian yang telah dilakukan di Sekolah Dasar Negeri 4 Amarang Kecamatan Tanralili Kabupaten Maros didapatkan hasil uji statistik dengan Chi-square diperoleh nilai $p=0,431$. Karena nilai $p>\alpha=0,05$, maka hipotesis nol diterima dan hipotesis alternatif ditolak. Interpretasi tidak ada pengaruh frekuensi makanan dengan timbulnya karies gigi pada anak usia sekolah di Sekolah Dasar Negeri 4 Amarang, karena responden yang frekuensi makanannya tidak kariogenik lebih cenderung mengalami karies gigi. Hal ini dapat dipengaruhi oleh perilaku menyikat gigi yang salah oleh siswa sehingga meningkatkan risiko terjadinya karies. Perilaku menyikat gigi ini berkaitan dengan perilaku pemeliharaan kebersihan gigi dan mulut yaitu yang meliputi waktu menyikat gigi, frekuensi, alat serta cara menyikat gigi.

Mengomsumsi makanan setiap hari dalam frekuensi yang banyak dapat menyebabkan anak-anak rentan terkena masalah gigi berlubang dari pada mengomsusi makanan kariogenik setiap hari namun dalam frekuensi yang sedikit.Karies gigi jika di biarkan akan memberi dampak negatif pada kualitas hidup anak-anak hingga beranjak remaja, bahkan sampai dewasa. Dengan mengetahui dampak dari karies gigi sehingga dapat memberikan informasi untuk lebih memperhatikan kesehatan gigi dan mulut dengan cara mengurangi komsumsi makanan kariogenik dan rajin menyikat gigi (Mendur, dkk., 2017).

Hasil penelitian ini sejalan dengan penelitian Fauzi (2016), menunjukkan bahwa terdapat hubungan yang tidak signifikan antara tingkat konsumsi makanan kariogenik dengan kejadian karies gigi pada anak SDN 2 Cirendeu Tangerang Selatan karena $p$-value $=0,678$ $>\alpha(0,05)$. Hal ini terjadi karena responden sudah menerapkan perilaku pemeliharan kesehatan gigi dengan baik sehingga mencegah terjadinya karies gigi, karena beberapa reponden dengan tingkat konsumsi makanan kariogenik yang tinggi yang menerapkan kebiasaan menggosok gigi dengan baik terutama setelah makan bebas dari karies gigi.

Menurut asumsi peneliti, tidak terdapat pengaruh antara frekuensi makanan dengan timbulnya karies gigi pada anak usia sekolah, karena responden yang frekuensi makanannya tidak kariogenik lebih cenderung mengalami karies gigi. Jadi, meskipun tidak terdapat pengaruh tetapi beberapa penelitian membuktikan bahwa frekuensi makan juga turut serta mempengaruhi timbulnya karies gigi. Sehingga perlunya membatasi makanan yang frekuensi makanan yang mengandung kariogenik. Makanan yang bersifat kariogenik bila dikonsumsi lebih dari lima menit di dalam mulut akan lebih berisiko menyebabkan karies karena semakin lama makanan ini menempel pada gigi akan menghasilkan asam yang lebih banyak pula. Jika kondisi tersebut dibiarkan akan menimbulkan plak yang menyebabkan karies gigi.

3. Pengaruh frekuensi makanan dengan timbulnya karies gigi pada anak usia sekolah.

Berdasarkan penelitian yang telah dilakukan di Sekolah Dasar Negeri 4 Amarang Kecamatan Tanralili Kabupaten Maros didapatkan hasil uji statistik dengan Chi-square diperoleh nilai $p=0,494$. Karena nilai $p>\alpha=0,05$, maka hipotesis nol diterima dan hipotesis alternatif ditolak. Interpretasi tidak ada pengaruh jumlah makanan dengan timbulnya karies gigi pada anak usia sekolah di Sekolah Dasar Negeri 4 Amarang, karena responden yang jumlah makanannya tidak kariogenik lebih cenderung mengalami karies gigi.

Jumlah makanan yang dikonsumsi seseorang atau sekelompok orang pada waktu tertentu. Mengkonsumsi makanan maupun minuman yang mengandung karbohidrat, dapat memicu bakteri didalam 
rongga mulut memproduksi asam, sehingga mengakibatkan $\mathrm{pH}$ saliva menurun dan akan terjadi demineralisasi yang akan berlangsung selama 30 sampai 40 menit setelah makan (Rahmayani, 2018).

Hasil penelitian ini sejalan dengan penelitian yang telah dilakukan oleh Hamid (2017), menunjukkan bahwa tidak terdapat ada hubungan pola makan dengan karies gigi pada anak kelas IV usia 8-9 tahun di SD Negeri 126 Manado Lingkungan 1 Kleak Kecamatan Malalayang Kota Manado Provinsi Sulawesi Utara ( $p$ value 1.000). Makanan yang mempengaruhi karies gigi dapat dilihat dari bentuk fisik, jenis hidratarang, dan kekerapan konsumsi. Pengaruh pola makan dalam proses karies biasanya lebih bersifat lokal dari pada sistemik, terutama dalam hal frekuensi mengonsumsi makanan. Anak dan makanan jajanan merupakan dua hal yang sulit untuk dipisahkan. Anak memiliki kegemaran mengkonsumsi jenis jajanan secara berlebihan, setiap kali seseorang mengonsumsi makanan dan minuman yang mengandung karbohidrat (tinggi sukrosa) maka beberapa bakteri penyebab karies di rongga mulut akan memulai memproduksi asam sehingga terjadi demineralisasi yang berlangsung selama 20-30 menit setelah makan.

Menurut asumsi peneliti, tidak terdapat pengaruh antara jumlah makanan dengan timbulnya karies gigi pada anak usia sekolah, karena responden yang jumlah makanannya tidak kariogenik lebih cenderung mengalami karies gigi. Jadi, meskipun tidak terdapat pengaruh tetapi siswa harus selalu memperhatikan makan yang dikonsumsinya karena jenis makanan sudah terbukti mempengaruhi timbulnya karies gigi pada anak. Siswa juga perlu memperhatihan bentuk fisik, jenis makanan, komposisi makanan, dan frekuensi konsumsi makanan kariogenik karena turut serta mempengaruhi kejadian karies gigi pada anak

\section{KESIMPULAN}

1. Ada pengaruh jenis makanan dengan timbulnya karies gigi pada anak usia sekolah di SD Negeri 04 Amarang Kecamatan Tanralili Kabupaten Maros.

2. Tidak ada pengaruh frekuensi makanan dengan timbulnya karies gigi pada anak usia sekolah di SD Negeri 04 Amarang Kecamatan Tanralili Kabupaten Maros .

3. Tidak ada pengaruh jumlah makanan dengan timbulnya karies gigi pada anak usia sekolah di SD Negeri 04 Amarang Kecamatan Tanralili Kabupaten Maros

\section{SARAN}

\section{Bagi Tempat Penelitian}

Disarankan kepada pihak sekolah untuk lebih sering memberikan informasi mengenai karies gigi kepada siswa, baik itu hanya lewat poster maupun dengan metode ceramah.

2. Bagi Stikes Nani Hasanuddin Makassar

Diharapkan hasil penelitian ini dapat dijadikan bahan informasi dan bacaan di perpustakaan.

3. Bagi Peneliti

Dalam penelitian ini selanjutnya diharapkan agar peneliti menggunakan variabel lain untuk melakukan penelitian tentang karies gigi dan melakukan penelitian lebih dalam.

\section{DAFTAR PUSTAKA}

Donsu, J. D. (2016). Metodologi Penelitian Keperawatan. Yogyakarta: PT. Pustaka Baru.

Fauzi, I. (2016). Hubungan Konsumsi Makanan Kariogenik dan Kebiasaan Menggosok Gigi dengan Karies Gigi pada Anak SDN 2 Cireundeu di Tangerang Selatan. Fakultas Kedokteran dan IImu Kesehatan UIN Syarif Hidayatullah Jakarta.

Febrian, Rasyid, R., \& Noviantika, D. (2015). Analisis Hubungan Jenis dan Frekuensi Mengkonsumsi Jajanan Kariogenik dengan Kejadian Rampan Karies pada Anak Usia 5-6 Tahun di Kota Padang. Andalas Dental Journal.

Hamid, S. A., Kundre, R., \& Bataha, Y. (2017). Hubungan Pola Makan dengan Karies Gigi pada Anak Kelas IV Usia 8-9 Tahun di SD Negeri 126 Manado Lingkungan 1 Kleak Kecamatan Malalayang Kota Manado Provinsi Sulawesi Utara. e-Journel Kperawatan (eKp). Volume 5, Nomor 2.

Hestiani, Yuniar, D. N., \& Erawan, P. E. (2017). Efektivitas Metode Demonstrasi (Sikat Gigi) Terhadap Peningkatan Pengetahuan, Sikap dan Tindakan Terkait Pencegahan Karies Gigi pada Siswa Kelas IV dan $V$ di Kecamatan Ranteangin Kabupaten Kolaka Utara Tahun 2016. Jurnal IImiah Mahasiswa Kesehatan Masyarakat, Vol. 2, No.5. 
Kartikasari, H. Y., \& Nuryanto. (2014). Hubungan Kejadian Karies Gigi dengan Konsumsi Makanan Kariogenik dan Status Gizi pada Anak Sekolah Dasar (Studi pada Anak Kelas III dan IV SDN Kadipaten I dan II Bojonegoro). Journal of Nutrition College, Volume 3, Nomor 3.

Mendur, S. C., Pangemanan, D. H., \& Mintjelungan, C. (2017). Gambaran Konsumsi Makanan Kariogenik pada Anak SD GMIM 1 Kawangkoan. Jurnal e-GiGi (eG), Volume 5 Nomor 1.

Rahmayani. (2018). Hubungan Pola Makan dengan Angka Kejadian Penyakit Karies Gigi dan Stomatitis di SD Muhammadiyah 16 Surakarta. Naskah Publikasi Fakultas IImu Kesehatan Universitas Muhammadiyah Surakarta. 